\title{
Commodity Chains in East Asia and the Development of the Electronics Industry in South Korea
}

\author{
SEOK-ChOON I.FW AND Byting-YOUNG PARK

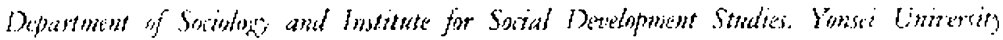

The development of the elatronics industry in the Fust Arian region is baraterixed in the "fhing geese pattem." Finming this flying seese foution. the most important fatn bas been the searth for lon' waye labor by firms of more det eloped countries. They relocate tbar ladw-intensins industries

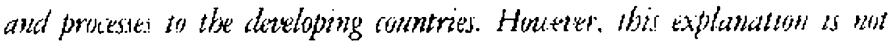
complete ixiause it does not explain bou the dicthomont of the Kurant destronicy indsist'y is breaking the existing commodity thain and forming nest oner. Like other fast grouing ecomomics of East Astan coumtries. Korta's electroniss industry began from importing foreign techntlogy and imessments mainly from Japan and the United Stater. Subseguently. Korean producers began to compete with the develofed conntries in consumar eletromics under

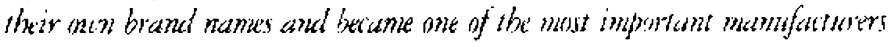
in the usald semionductor industry. In this regitul. the Korean electronics industry demanstrates an exceptional development pattem. Th explain this. ue' must focus on the role of the gowernment and the indristicil strwture. The distint derelopment of the eleatrmics industry in Kowa is atributed to the interation betuen local froms belonging to toutobl. and gontmment wppowr.

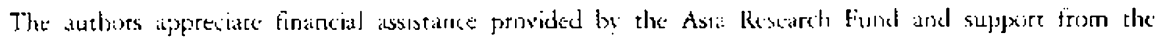

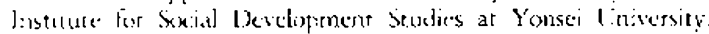

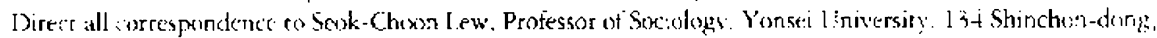

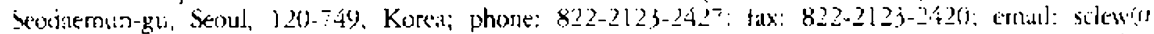

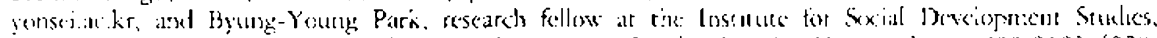

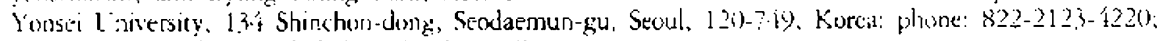

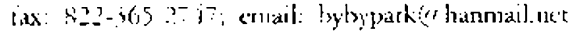




\section{INTKODUCTION}

I In the development of Japan and East Asian Newly Industrializing Economics (NICs), the electronics industry has been one of the most important srrategic industries for economic growth. ${ }^{1}$ Furthermore, the economies of Southeast Asian countries, such as Malaysia and Thailand, have developed very rapidly due to the growth of the electronics indusery (Tan 1996). The electronics industry as such should be regarded as the most important industry for economic development. However, except for the East Asian NIC and some Suutheast Asian countries, most developing countries in other parts of the work bave not been able to develop or even enter the electronics industry.

From the late $1960 \mathrm{k}$, the Korean clectronics indusery has shown tremendous growth. Production and export of electronics increased enormousty in the 1970s and the 1980)s. By the early 1990), the new Korean manufacturers were successfully competing with the existing brands (such as those from the United Stares, Japan, and W'stern Europe) in the international consumer electronics market. Also, the Korean semiconductor industry became the most important supplier of Dynamic Random Access Memory (DRAM). How could this happen? It is gencrally assumed that developing countries have difficulty breaking out of the existing commodity chains (Gereffi et al. 1994; I lenderson 19\%). In this regard, the development of the Korean electronics industry is an ideal test case: which deserves careful investigation.

Commodity chains, defined as "a series of linkages berween sites involved in producing part of an overall product for sale on the market" (McMichael 1996, 295) or "a network of labor and production processes whose end result is a finished commodity" (Hopkins and Wallerstein 1986, 159), have been continuously reshaped in the workd economy. Ihis concept is relevan insofar as it explains changing international competiciventess or division of labor. Such changes are underscoud as the sutcome of the movement of capital in core countries. As Gereffi et al. point out, "there are twe primary factors that explain shifts in the geographical location and organization of manufacturing in global commodity chains. One is the search for low wage labor, and the other is the pursuit of organizational flexibility" $(1994,6)$. From this perspective, however, the domestic factors of semi-peripheries or peripherics are hardly considered.

The development of the Korean electronics industry from low-level parts assembly to high-level brand name exports cannot be adequately explained by those two factors, since the breakthrough has been led mostly by domescic firms. In this sense, the suceess of the Korcan case, which has been able to form new globsal commodity chains along with the existing ones, is indeed exceptionat and we need to consider how the nationstate and the domestic industrial structure allow for certain degrecs of freedom against the external constraints.

This paper atcempts to explain the rapid growth and the exceptional breakthrough of the Korean electronics industry. We will start with a general review of the electronics

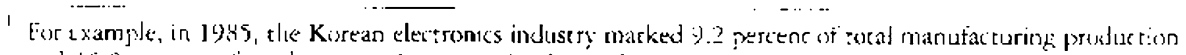

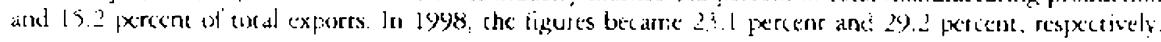


industry in a worldwicke context. "Then, we will move to a case study of the Korcan electronics industry to show the hiscorical pattern of development mainly in quantitative terms. Next, we will analyze the flying geese pattern of the Lase Asian economy, in which some countries can gain new advantages in the changing intctnational division of labour. Finally, we will rocus on how domestic factors, such as the role of the government and the internal inclustrial structure, made a qualitative breakthrough in Korea. A brief discussion of the implications of the findings will conclude the paper.

\section{'I'HE ELECTRONICS INDUSTRY \& THE DEVELOPING COLN'IRUES}

"The story of industrialization in che developing world in large measure has lecen a scory of the emergence and expansion of two sectors: textiles and cectronics" (Henderson 1994, 258). Textile and apparel are important segments of the economy for developing countries. In the inter-industry division of labor, developing countrics can begin their catch-up process from these industries because of their labor-intensive characteristics. In fact, these industries have shifted the main prolucing areas from the developed to the devioping conomy. 'The high wage level of the developed econony was the main force behind this shift.

Compared to the rextile and apparel industries, the clectonics indestry is both a capital-intensive and knowledge-intensive industry. Ar the: same time, the final products are compused of numerous parts and components, and the production of these electronic goods often involves a great deal of labor-intensive processes. Furthermore, the scparation of production in clectronics is tasict than any other capital- or technology-incensive industry. Therefere, since the $1960 \mathrm{~s}$, major electronics producers in the developed cconomies have relocated therr production lines to the developing countries to secure low wage labor and expanding markets.

As Henderson (199) points oue, clectonics as such is a more inportant industry than textiles in the develomment process. Above all, developing countries can initiate their technological upgrading with the advent of the electronics industry. Furthermore, electronics is one of the fastest growing industrics in the world economy. The world clectronics industry marked an average 11.4 percent annual growth rate from 1985 to 19y0. In addition. the electronics industry has a variery of add-or effects on other related industries. Also the possibilities for the developmene of new products and innowate ion of production processes are likely to appear, parricularly in this rapidly expanding sector of ecomony.

However, these potential benefits do not always materialize for all economies. Alowe: all, for devcloping economies to enter the electronics industry foreign capital and technology are needed. In this sense, the perspertive of commedicy chains provides useful insight. 'lo gain access into the electronics industry and to acquire its benefits, many obstacles must te overcome along tour stages of development. Developing countries should start their technological upgerading processes at the "implemetuation" stage. In 
this beginning stage, the electronics industry is developed as an import-substitution industry or as offshore proxluction. Technology at this stage is usually transferred as packages from toreign investments. The next stage would be "assimilation." During this stage, local firms acquire technological skill by "learning by doing," and gain comparative edges in low-end products. This stage is followed by the "improvement" phase. Ituring this period, innovations are made with imporred technology, and technology transfer can be achieved through licensing. The final phase is the "independeat $R \& D$ " stagc. Technology export and investment into low wage economies oxcur at this stage to form a global commodity chain. Local actors are important in these development processes because it is very difficult to receive technological upgrading from foreign firms

If we classify the electronics-producing countries inco four groups along the stages of elevelopment, the United States, Japan, and Western Furopean nations should belong in the final stage group. Independent R \& D and a balanced development of machinery, components, and materials in electronics are characteristics of these countries. The third stage group would be the Easc Asian NICs induding Korea, Taiwan, Singapore, and Hong Kong. Rapid development and increasing export of electronics products are common in these countrics. 'lhey try to concentrate on manufacturing capital-and technology-intensive parts and assembling final products tor export. Although a gap berwetn the last stage and the third stage group still exists, the third stage group has been able to compere with the last stage group in some products such as IDRAM, VC.Rs, and computers. Southeast Asian countries such as Malaysia, Thailand, and Indonesia would belong to the sccond stage group. They concentrate on labor-intensive parts and component production for the international market. Foreign investments in the form of joint ventures are the prevailing mode of production in this group. Latin American countries such as Brazil and Mexico belong to the first "implementacion" stage group. In these countries, production is directed not at the international market but at the domestic market for import-substitution.

As shown in Table 1, more than half of the wotd's clectronics market has been dominated by the United States and Japan from 1986 to 19x6. The United Stares has been the largest producer and Japan has been the biggest cxporter throughour these ten years. Aside from these two giants, only a few Western European countries showed significant figures for production and exports in 1986. The rest of the world remained insignificant.

However, in 1946. che shares of East Asian NICs changed dramatically. Korea became the fourth largest producer of electronics, closely chasing the third largest, Cirmany. The exports of Singaxore and Hong Kong were larger than those of fiernany and Britain. By 1996, the East Asian NICs had become important producers and exporters of clcctronics in the world markets. Together, they contributed 12.5 percent of the world's products and a quarter of rhe world's exports. In addition, Southeast Asian councries, such as Malaysia and Thailand had the fastesc gruwing economics in electronics production and exports during the 10-year period.

Table 1 also suggests that the progress of the electronics industry in the developing 
countries was not even. Most of the other developing countrics, which are not listed in the table, were unable to enter into the electronics industry. Only four Last Asian NICA and a fow Southeast Aslan countrics reached the potential of the electronics industry. However, among the sucress cases, the degree and scepe of success varies. It secms chat the fous East Asian NICs have moved from being primary proxluction contractors (1) intermediarics, or the middle-man position, in electronics rommodity chains.?

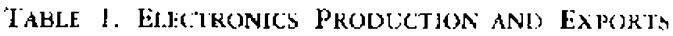

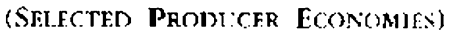

\begin{tabular}{|c|c|c|c|c|c|c|}
\hline \multirow[b]{3}{*}{ Worlas Torat } & \multicolumn{3}{|c|}{1986} & \multicolumn{3}{|c|}{$19 \times 3$} \\
\hline & $\begin{array}{c}\text { Production(A) } \\
(C)\end{array}$ & $\begin{array}{c}\text { Exports(B) } \\
(\%)\end{array}$ & $\begin{array}{r}(B / A) \\
\times \quad l(X) \\
\end{array}$ & \multirow{2}{*}{$\begin{array}{c}\text { Production(A) } \\
(\%) \\
1,06 \mathrm{i}, 9 \times(1)(x),(1)\end{array}$} & $\begin{array}{c}\text { Fxjourts(B) } \\
(\%)\end{array}$ & \multirow{2}{*}{$\begin{array}{r}(B / A) \\
\times \quad 1(X) \\
\quad 68,0\end{array}$} \\
\hline & $60 ? 573: 0000$ & $185.9 \%(100.0)$ & 40.2 & & $=2-t, 6(x)(10(0), 0)$ & \\
\hline Nerth Americi & & & & & & \\
\hline & $=178,4) 5(38.5)$ & $29,82 ?(16.0)$ & 16.7 & $3(x, \ldots, \cdots(2 \times, \ldots)$ & 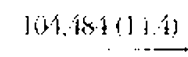 & 34.8 \\
\hline Suth America & & & & & & \\
\hline Brazil & $5.48)(1.2)$ & $648(0.3)$ & 11.8 & $(9) 1: 0(: .8)$ & $1,056(0.1)$ & 5.5 \\
\hline Eur'spe & 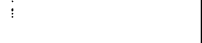 & & & & & \\
\hline Cersmanl: & $3.315168 i$ & $19.518(10.5)$ & 61.4 & $3 .,(03)(+8.8)$ & $i,(0 \times 1(59)$ & $x j{ }^{-}$ \\
\hline Brititis! & 10.81 (1.3) & $11,385\langle 6.1\rangle$ & sirí & $34.108(2.7)$ & $40,32)(50)$ & 101.2 \\
\hline France & $21,3 \%)(16 !$ & $8.679\{4.7\}$ & 和6 & 35.5510 .39 & $29.111: 3.9$ & 79.1 \\
\hline Asial & & & & & & \\
\hline Japin & $123,843,26,43)$ & $51,533(27.7)$ & 41.6 & $\therefore+4,45 \div 0 ? 009$ & $1\left(0^{-}, 30\right):\{1+8\}$ & $43 x$ \\
\hline Korta & $9,17^{7}(2.0)$ & $6.372(3.4)$ & 6) & $18.1 .36(4.5)$ & $32,9(6)(1.5)$ & $6 x .5$ \\
\hline Sirmganpure & 3,409 (1.2) & $6,675(3.6)$ & 123.5 & $1,507(j .1)$ & $6(0.544(1) .2)$ & 152.6 \\
\hline 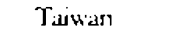 & $\because 67 ?(1.7)$ & $6,2(0)(3.6)$ & 81.5 & $32,125 \quad(3,6)$ & $3 \therefore, 8 k ? \quad(\therefore, 8)$ & 308.6 \\
\hline Hong Kisng & $\left.t_{, 262}, 0.4\right)$ & $6,63(1)(3.6)$ & 155.3 & $8,-14(0) 8):$ & $18,607\{6.7\}$ & 556.9 \\
\hline Malaysia & $2.302(0.5)$ & $2,600011.49$ & 108.7 & $39,5 \div \div\{2.8\}$ & is, $-41(+4)$ & 119.5 \\
\hline Thailans: & 84. $(0.2)$ & $518 \quad(0.3)$ & 62.2 & $: 9.110(1.8)$ & $\therefore$ : & $73:$ \\
\hline
\end{tabular}

Nate: * Wist Germian: in 1986

Soure: Eisovice Yestons of World Eieceromes Data.

Profucers in the NICs started overseas investments in Southeast Asia in the 1980 s. Thus, producers in Southeast Asian countrics were able to grow because of outside: investment from the NICs as well as Japan. Although the sucecss of the NICs seems to be outstanding, they still have difficultics with their middle-man status in the comnodity chain. 'The NICs are subject to the TNCs or large retailers, who control whether they can gain the porential benefits of high value-added noxtes on a full scale (Henderson 199) Hor further developnem, an escape from this pusition is necessary.

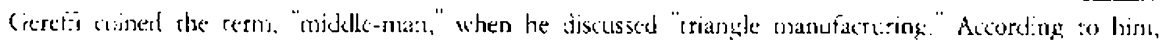

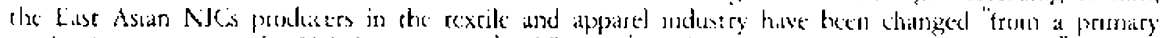

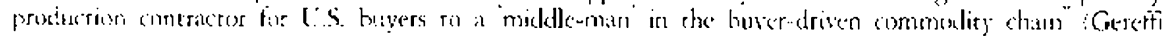
:ye)th. 23.1. 
In this context, the Korean consumer electronics and semiconductor industries are the exceptional cases which escaped such constraints. In fact, as Honderson argues, "in comparison with the output of the leading developed industrial economies, the electronics industrics of the developing world, with the exception of that of Korea, remain relatively minor players" $(199 / 4,259)$. Although much of the electronics production in Korea is still undertaken by original equipment manufacturing (OFM), some thatbol firms have been able to produce and export electronics products for the international market under their isw brand names. Samsung and LG are representative cascs of this breakthrough.

\section{THE DEVELOPMENT OF THE KOREAN EJECTRONICS INDUSTRY}

Flectronics has been one of the fastest growing industrics in Korea for the past threc decades. As shown in Table 2, the rocal production of electronics in $19 \% 6$ was over 15.000 times that of 1965 . Electronics exporr in $19 \% 6$ was over 20,000 times that of 1965. In 1496, the rapidly growing electronics industry marked 13.6 percent of total manufacturing production and 31.8 percent of total exports in Korea. By 1996, Korea became the fourth largest producer and the sixtl largesc exporter of clectronic goxds in the world.

TABLE 2, ELECTRONICS INIOTTKY IN KOREA

\begin{tabular}{|c|c|c|c|c|}
\hline & 1965 & 1975 & 1985 & $19 \%$ \\
\hline Proxisction Manutacrusing Toral & $1.571(100)$ & $2(1,1 \div 6(1) x(x)$ & $88.841(16(x))$ & $151.228(100)$ \\
\hline Elecironics & $11(0.7)$ & $8(10)(4,2)$ & $? .285(8.2 \%$ & $61.367 \div 13.61$ \\
\hline Exports Totil & $175(1(x))$ & $5.081(100)$ & 30,$283 ; 110 \times 13$ & $130.715(10(0)$ \\
\hline Electroniss & $2(1.1)$ & $582(11.5)$ & $+590 \div 15.23$ & 41,$223 ; 31.8 ;$ \\
\hline (Expures/ Prodicrion) $\times 100$ & 182 & 67.7 & 6.3 .0 & 67.2 \\
\hline World Ranking Prexduction & п.а. & 13 & 7 & 4 \\
\hline t.xporsts & п.а. & 13 & 11 & 6 \\
\hline
\end{tabular}

Soterce: Kurea [nstilute tor Indlustrial Economses and Trate: iKJET].

In consumer electronics, Korean brands are now quite familiar to many people throughout the world. Recently, Korean electronics manufacturers have started to develop and proxluce high value-delded products such as LCD's (liquid-crystal display), I IDTV's (high-xlefnition relevision), and MP3 players. The achicvement of the semiconductor industry in Korea is also outstanding. Except for offishore production, the history of the Korean semicondureor industry began in the carly 1981)s. Afrer one decade, Korea becane one of the major producers of semiconductors. Now Korcan manufacturers are the greatest MOS (metal oxide semiconductor) memory hip producers and exporters in the world. 
The electronics industry in Korea began to take shape in 1954) when Goldstar started to produce vacuum-tube radios. Afterwards, from the mid-19(60), there was a wave of L.S. scmiconductor tims investing in Korca. Komy, Signetic, Farchikd, Motorola, and IBM foured investments into Korea to establish assembly lines. At that time, Japanese firms were rarely present in Korea. It was from American investments that local Korean producers learned how to assemble semiconductors. Producrion of black and white televisions also started in those days.

During the $1970 \mathrm{~s}$, Japanese electronics manufacturers beyan to show strong interest in Korea, atter the Korean government adopted an industrial promorion policy from the late 196 (s) wo attract foreign investment and incresse export. As a part of ituse cifores, the Masan area was declared a free trade zone and the city of Kumy was constructed as an industrial complex for electronics marufacturing. In this favorable environment, Japanesc electronics firms nushed into Korea, where they could avois trade contlicts with the Iinited States by detouring Japanese exports through Korea.

During the 1970s, firms with foreign difect investment (IDI) constituted around 60 70 percent of total electronics industry production and exports. For foreigners, Korea at this period was the best place to obtain high-quality labor at low wages and to enter a preferential investmente environment. by the late 1960), U.S. firmis ie Kureil mushroomed in the arca of assembly lines for semiconductors, while Japaresc firms in Korca from the 1970s flourished in consumer efcetronics and parts proxtuction.

Since the mid-1680s, FDI in Korea has demonstrated different patrertus. Ine to the tast growing economy, Korea's domestic market has gained importance and the low wage advantage no longer exists. In this context, forcign investors shifted their interest to the Korean market. Accondingly, offshore production in Korea significantly decreased during this period.

[1] I and joint ventures were critical to the development of the Korean dectronucs industry durneg its early stayes. During the 1960 s and the 1970s, the Korean cecteronics industry experienced the implementation and assimilation plates with the Jeavy presence of forcign investment. Korean electronics producers were able $t$ ) start learning production technolugy from forejgners. However, only a limited amount of capital was invested in R \& D, plants, and equipment. Any serious effort coward the next stagc of development was not in the interests of foreign firms in Korea.

It was the investment of loxal baebol firms that enabled the Korean electronics industry to enter into the next stage of development. Fron dhe late 1970s, loxal firm investment increased cromously to upgrade production systems. During the $1980 \mathrm{~s}$, thatert companies began to put independent $R \& D$ systems in order. They also increased investmen: in semiconductors, personal computers, and VCRs. As a result, production capacily tremendously expandex.

Corresponding to these technological developments was a change in the main products for the electronics industry. Korean consumer electronics products stated with the assembly line if radios in the 1960). Through the assembly of cassetce tape recorders and black and white televisions in the 1970 , Korean firms began to produce color televisions 
and VCKs in the 1980s. Camcorders, CD players, DVDs (digital video displayers), digital televisions, and MP3 players are now produced in Korea. In the industrial electronics area, the main products changed from magnetic phones to electronic, cordless, and nubbile phones, and then later to computer and mobile conmomication equipmest. In the areat of electronic parts, Korea has become one of the largest producers of semiconductors.

Table 3. thi Prodichion Strictloke of the Korean Ej.ectroniss INimistry

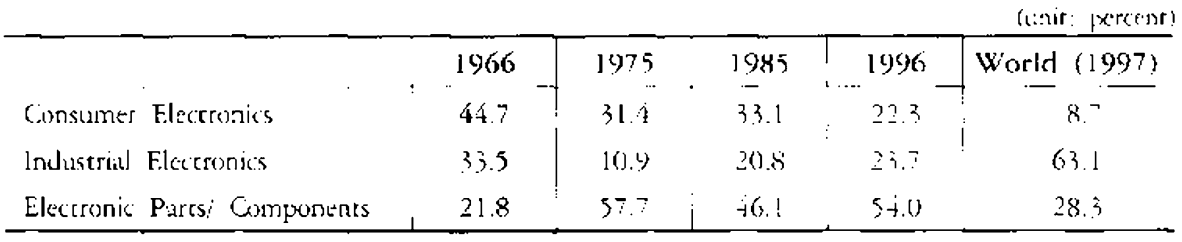

Solstre: KIF.'

Table 3 shows the structure and development pattern of the Korean electronics induscry. Compared with the world production structure, consumer electronics occupicd significant portion. But since the 1980 s, the relative importance of consunxer electronics has gradually been reduced. This decline came with the growing development of industrial electronics and electronic parts, mainly semiconductors.

The export of Korcan electronir goods reflects the production structure. In the $1990 \mathrm{~s}$, export of industrial electronics and electronic parts increased, in relation to the change made in consumer electronics. Notably, the export of etectronk parts has increased very rapidly duc to the semiconductor. Since the nuid-1980s, the serniconductor has become extremely important to the Korean electronics industry. For example, in 19\%7 atud 1998, the expon of semiconductors was over $\mathbf{4 0}$ percent of total electronics exports. The increase of exports in industrial electronics for the same period was, however, very small. In consumer electronics, not only compositional propositions but also the amount in absolute terms of export has dedined since the mid-19y) (FIAK 109)?.

The main markets for Korean elecronics export have been the Tinited States, Furopx. and East Asia. The United States and Japan have been important trate partners for Korea. In 19\%6, exports to the U.S. market reached over a quarter of total electronics exports, and Korea has enjoyed a continuous trade surplus with the United States. However, Korea has suftered large trade deficits from Japan. The imports from Japan have been mainly industrial clectronics and core parts.

These trends reveal an importane structural pattem of the Kotean clectennics indusery. The Korean electronics industry impores capital equipment, plants, and core components such as non-memory semiconductors and condensers mainly from Japan, and exports final products to the I Inited States. This trade patern has been estahlished because the Korean electronics producers have imitated Japanese products and production settings while the Japanese manufacturers have retained core technology and components. From the 1980s, efforts were made to avoid this situation from the government as well as 
from the business sectur, yet the efforts were in vain since the pattern persiscs coday. After the 1980s, the Korean electronics industry began to lose its comparative advaruage over low-end parts and some consumer electronics. A sharp increase in proxluction costs, espectally in lator, cook form. As an alcermative, Korean electronics prexducers began to relocate their producrion processes. Table 't shows Korean electronics protucers' investments abroad. The main regions of relocation have been Sourheast Asta and the Linited States. Initially, Kotean producers relocated their assembly lines or compons nt production ti) Southeast Asia to secure low wage labor. Many Korcan manufacturers have nnvested in consumer electronics and parts production in Southeast Asia. Secondly, investmenc in the United States was motivated to facilitate advanced technology transter, w prevent trade conflicts, to expand marketing ability through existing brand names, and to secure marketing nerworks from U.S. companies. The lasge-scale investments of Sarnsung, Hyundai, and LG in the United States were mainly achevete in the form of $M \& A$ (merger and acquisition).

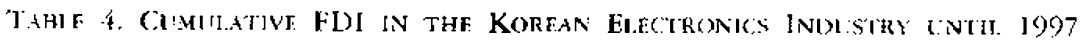

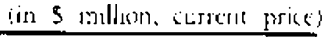

\begin{tabular}{|c|c|c|c|}
\hline & & Amounc & Casest \\
\hline Desectrics & is Industry' Tostil & $(0,755 ! 100(1)$ & $1,7: 5<100,0)$ \\
\hline \multicolumn{4}{|c|}{ Fusincss Types } \\
\hline & Proxluctioss & $j, 658(5+2)$ & 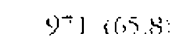 \\
\hline & S.les & $1.730(.5 .60)$ & $3612 \geq 36$ \\
\hline & $k \propto 1$ & $1510 ?$ & $37175 i$ \\
\hline & Others & $\therefore .216(18.0)$ & 13300 \\
\hline \multicolumn{4}{|l|}{ Region } \\
\hline & $\Lambda s_{1: 1}$ & $2,285(3,3.8)$ & $903<61.2$ \\
\hline & Anericas & $2.896(12.9)$ & $7 \div 2(26.7$ \\
\hline & laurupe & $1,516(22.4)$ & $175411.4:$ \\
\hline & Uthers & $36(1) .8)$ & 1) \\
\hline
\end{tabular}

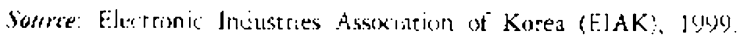

The Kurean deceronics indusry, as with other Fast Asian NICi, las shown tremendous growth. But there is a more important dimension to consider than the quantity of growth. Korean producers have begun to break the existing buyer-driven commodity chain in some consumer electronics, and cransformed into one of the main producers in the global semicondector commodity chain. To explain this gualitative change, we will foxus on domestic factors such as the initiatives of the Korean government and che response of thathal firms. Betore we do so, we will describe the flying gecse pattern of East Asian development in electronics to understand why the clectronics industry has developed so rapidly in East Asia. 


\section{'IHE FLYING' GEESE PATTERN OF EAST ASIAN DEVELOPMEN'I AND COMMODITY CHAINS IN THE ELECTRONICS INDUSTRY}

The development of the Last Asian economy has been characterized by the "flyiug geese" pattern of growth. This refers to the "multi-stage process of catcling-up by all the countries involved in an area" (Ichimura 1998, 25). McMichael (19)6, 84) and Cumings (1987, 15-16) poine out that this flying geese pattern came to exist by the effect of produce cycles. When firms from the developed countries enter higher technologyintensive and high value-added industrial sectors, they tend to relocate their existing industry or production proxisses to the developing economies, low wages being the main motivator. In addition, firms tend to invest in different regions to pursue organizational flexibility. The rising activism for environmental protection in the devcloped nations is anorher factor for offshore movement.

In Easc Asian growth, Japan Icads in technological innovation. Korcat and Tatisan are following the trajectory of Japanese development. Southeast Asian countries such as Malaysia, Indoncsia and Thailand, meanwhile, are using capital, technology and equipinent from Japan and the NICs to follow the patlus their predecessers paved. According to the stages of technological development, Japan belongs to the advanced stage. Japan rctains comparative advantages in industrial electronics wherc higher level teclnology and incensive capital investments are essential. The East Asian NIC's including Korea, 'Taiwan, and Singapore all occupy the third stage of development. However, their main proxlicts as well as their industrial structure reveal divergent patterns.

Korea's main development has been in consumer electronics and semiconductors. Korcan producers, suescly big bouelol firms supported by dis: government, still inpore some parts, especially higher technology intensive parts from Japan, but they conpere with the last stage group through their own brand name products. In centrast, the Taiwanese electronics manufacturers, mostly small- and medium-sized firnss based on "quanxi network," are geared towatd the production of microcomputers (Orru et al. 12)97; Chan, ed. 2000). Singapore produces high technology-incensive electronic parts, bur most of the producing cumpanies are foreign ones, in contrast to the domestic firms of Korcan and Taiwan.

Southeast Asian countries, particularly Malaysia, Thailand, and Indonesia can be included in the second stage group. Electronics production and expors in these countrics have been rapidly growing since the introduction of an export oriented industrialization policy in the 1980s. They have concentraced on the manufacturing of low-end products and lalwor-ineconsive parts or components, mainly through forcign direct irvestment.

The strategy of Japanese firms has been the main force behind shaping the flying geese partern of the East Asian plectronics industry. Until the 1970), Japanese investment in Southeast. Asian countries was limited to small joint ventures. At that time. Southeast Asian countries pursued import-substirution strategies, and Japanese firms werenot interested in their rather limited domestic markets.

However, the situation began to change in the 1970)s. Due to trade conflict with 
the L'S. and Western Europe, Japanese firns needed ro invest in VICs as a detur for their exports. The export-oriented induscrialization strategy in Southeast Asian countries enabled Japanese firms to take advantage of the newly established platform tor export. At that titne, declaring export processing eoncs or free trade zones was becoming popular in the region. Korea and Tawwan offered the mokel for this investment partern.

Investments by Japanese firms during 1979-85 were stagnant. However, affer 1985, Japranese investment in Southeast Asian countries began to increase again (Sirikraj 1944), as the Japanese yen began to appreciate steeply against the U.S. dollar. At the same rime, che prexduction costs in NICs (Korea, Taiwan, or Singapore) were gettung higher, and Southeast Asian countries were ready to offer incentives to forcign investors. Japantese firms beysin to pour a large anount of investments into ASEAN (Asseciation of Southeast Asian Nations). It was also during this period that waves of Korean investment into Sourheass Asia began to oxcur (K. Lee 1995).

Japanesc and NIC. investment into Southeast A sia have contributed to the tlying gcesc pattern of development in the East Asian electronics industry. The pattern initiated investment and technology transter from Japan as well as the relocatiun of production processes. It could also be argued that che patcern is impossible without the exportoricnted strategy of the region in general. Each country produced electronic gexods for the international market in a specific sector where it holds a compararive advantage.

In conclusion, the economic development of the East Asian region is characterized by the flying geese pattern. The most important factor in the flying geese pattern has been the low wage labor priority by firms of more developed nations. They relocate their labur-incensive industries and processes to developing countries. The development of the Last Asian region can be analyzed in this respect. However, this explanation is only partial, because it does not attribute the Korean electronucs industry for breaking existing commolity cluains and forming new ones in selected electronics products.

\section{THE DOMESTIC FACTORS: GOVERNMENT AND INDUSTRIAL STRUCTURE OF THE EI.FCTRONICS INDUSTRY IN KOREA}

It is a well-known tact that the Korean economy was mobilized for rapid groweh under the tight hold of political power (Lew 1997). The Korean government enjoyed a firm cuntrol over the industry, effertively enforcing businesses to follow its poilicy recommendations. In this process, those who were obedient to state initiatives were rewarded and thos: who were against them were: peralized (Lew 195)67. The main podicy measure of the Korean governmene was the control of hank credit. In the starc-controlled banking system, the government and large businesses formed a "quasi-internal capital market" (Lee 199?).

The electrunics inclustry in Korea was no exception. State favors have becen critical factors for the growth or deach of individual firms in the Korean elcctronics industry. Big business groups, or dhatrol, have been in a position to take advancage of state policy, 
which is why they have played a leading role in the development of the Koran electronics indestry under the guidance of the "developmental statc."

In the uni-1060s, the Korean government adopted systematic industrial policies in order to develop strategic export industries. As priorly discussed, the electronics industry is composed of divergent processes, some of which are labor-intensive. Thus, the Korean government pursued the development of the electronics industry because its labor-intensive characteristics could well match the highly-trained labor force in Korea. In 1966, the government founded a new public institution, KIST, to support $\mathrm{R} \& \mathrm{D}$ activities in the electronics industry. To expand exports, the Five-Year Plan for Electronics Preduce Export (1967-71) was formulated. The Korean government alsi enacted the Filectronics Industry Promorion Iaw to be followed by the Eight-Year Plan for Floct ronics Industry Promocion (1969)-76). At the same time, the governunent tried to attract forcign investment by establishing supportive institurions and laws. In 1969, a southern mediumsized city, Masan, was designated a free trade zone, and Kumy, a nearby city, was establishted as an industrial complex for electronics production.

[uring the 1970s, the primary strategy of the government in electronics was export promotion by way of imported parts assombly. This strategy was coupled with increasing forcign investment. Fortunately, forctgn investors at that tirke were actively secking out low uage labor and favorable conditions for their uffshure investments. Due to these policy measures and international concerns, a sizable electronics industry came to exist in Korea by the end of the $1970 \mathrm{~s}$.

With the advent of the 1980s, the Korean government revised the Electronics Industry Promotion Law to provide funds for development. A new master plan was established in 1982, which introduced measures for the development of specific electronic products such as computers and semiconductors. This plan cocouraged large-scale investment in the scmiconductor industry by Korean electronics manufacturers. Parallel witl efforts from the privare sector, the government initiated a support program en teclunok)gically upgrade private semiconductor firms. Since then, the Korcan semiconductor industry has experienced an extremely rapid growth.

The Korean government also strongly excouraged local firms to produce core parts components of electronics, which were mostly being imported from Japan at the time. In order to catch up with Japan, the Korcan government initiated "G-? Projects" in the 1990s to bridge the technological gap and take on higher value-added nodes. lhese statc etforts turned out to bc partially successful.

In shore, the Korean government actively pursucd an export-uricnted indust rialization strategy and promoted the production of electronics ourput. In the carly stages, efforts were made to attract foreign investment for assembly lines. But later, teclinological upgrading was the most important factor in eliciting government support. The government prepared master plans and provided incentives to local and forcign firms of follow them. Also, in the case of the semiconductor industry, the Korean government did not hesitate to adjuse its original stsategy to the demand of $\mathrm{k}(\mathrm{x} a \mathrm{a}$ firms. In the early 198()s, the Korean govermment conducted at promotion plan for the scmiconductor industry. The plan's 
main strategy was import-substiturion of semicunductors. But the thath did not follow this diretive, and instead make large-scale investments for the international market. However, this contlict was resolved very quickly through an altered strategy in the mit19805, in which the government began to support lixal firms' $R$ \& $D$ in semiconductors for the sake of exports. ${ }^{2}$

In a sense, the Korean electronics industry is a very exceptional casc, because it bas been able to break the existing buyer-driven commodity chains in the world econony. In che lyos, large firms, relying on thaebre, began to export under their own brand names. In buycerdriven commodity chains such as consumer dectronics, it is very difficult 10 move trom the position of "midde-man" because of the existence of larese retailers and cransnational corporations. In order to break away from these chains and export under domestic brand names, enormous investments in production facilities and market ing networks are indispensable. This transformative brcakthrough was achicved by local firms in Korea with government supporc.

In regard to the semiconductor industry, Korea became one of the biggest producer counerics in the world. The semiconduceor industry, especially the DRAM industry that Korcan producers have concentrated on, is a very risky sector. Enormous investments are necded for cnerance into the sector, and fuctuation in demand and price is extreme:ly high. In addition, this sector is characterized by rapidly changing technology. For these' reasons, it is very difficult for developing economies to enter the DRAM industry. Korean producers of thatiol have invested in the semiconductor industry since the 1980s. The magnitude of their investments was spectacular, In 1992. Samsung, LG, Hyundai, Daewox), and Korca Llectronics, taken together, invested abrut $1,770,000$ million won in seniconductor plants and equipment. In the same year, total investments in plants and exuipeneret in Kurea's serniconductor industry (about 1,795,000) arillion won, approxitnatedy LIS. \& 2.20) million were over 19 percent of toral world investments (abuut IIS. $\$ 11, \%()$ million). The invesements reflected 28.7 percent of the toral sales of Korcin semiconductors (about 6,264,(X)0 million won). Such an enormous amount of investment is only possible through large chatol groups.

To explain the exceptional development of the Korcan clectronics industry, we mast focus on the Korean big business bateol groups. As discussed above, huge investments and eechological foundacions are needed to alter the existing commodicy chans of consumer electronics and to gain access into the DRAM indestry. Both are very risky projects. Yet thatinl are able to not only invest on a large scale, bue they can lower their risks due to their size and diversification. ${ }^{4}$ The big electronics companies belonging to thathol secure a market for their products and take advantage of incra-corporate transfers of technology, know-bow and trained personnel (Lew 1996, 269)-:0).

Foreign investments were helpful for a certain level of ecchnology transfer, especialy

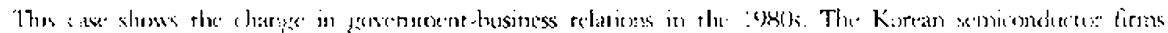

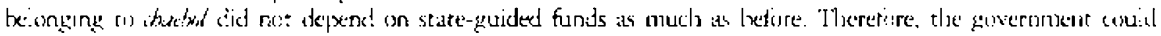

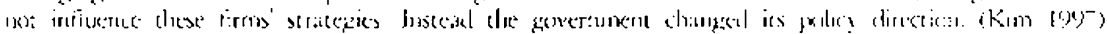

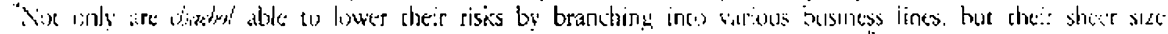

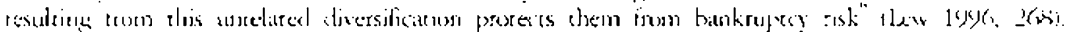


in the carly stages of development. However, forcign investments were not expected when it came to core technology and higher valuc-added nodes. It was at this point that the big Korean firms played a critical role. Since the Korean electronics industry was developed mainly by companies belonging to conglomerates such as Samsung, I.G. Daewoo, and Hyundai, their extensive, large-scale investments made the breakthrough possible. Furthermore, the state did not hesitate to support chabbl firms. Thus, the distinctive development of the Korean electronics industry has been straped by the alliance between big companies belonging to chaebol. and the grovernment.

\section{CONCLUSION: IMPLICATIONS FOR DEVELOPMENT THEORY}

The electronics industry is an essential industry for economic development. Duc to the easier division of production processes in the electronics industry than in other industries, as well as its labor-intensive characteristics, the developed countries rended to relocatc their production lines offshore. The four East Asian NICS, followed by the Southeast Astan economies of Malaysia and Thailand, took asdvantage of this opportunity. In this regard, shifts in the international division of labor offered the chance for development to Fast Asian NICs and Southeast Asian countries.

This international shift has been coupled with the export-oriented development strategy of the region. As discussed earlier, East Asian NICS and some Suutheast Asian countries adopted an export-oriented strategy and began to attract foreign investment. Although the strategy cannot fully explain their economic success, and the role of foreign investment diverged across countries, all nations witnessed rapid development coupled with growing production and exports. The relevance of the commodicy chains perspective lies in this proint.

Desprite overall of success in the region, Korean consumer electronics and semiconductor industrics show exceptional development patterns. Altering existing commodity chains has been achieved only in Korean consumer electronics and the formation of new commodity chains has occurred in the Korean semiconductor industry. In this regard, the development of the Korean electronics industry is an extraordinary case. Admittedly, the structure of the Korcan electronics industry is uncven and chere still exists a wide techinological gap between Korea and the kading countries. I fowever, Korcan consumer electronics producers have begun to compete with the United Statts, Japan, and Western European ceonomies, and have come to be one of the biggest producers in the semiconductor industry.

This type of development is not accidental. To escape from offshore assembly, largescalc investment by domestic firms in equipment, plants, $R \& D$, and marketing was necessary. The breakthrough was engineered by local Korcan firms of which the majurity are inembers of ibatbol groups. Along with the chatol-oriented industrial structure, the role of the government has becn crucial in the develupnent of Korea's clectronics industry. During the industry's early stages, the government mate effors to atcract forcign 
investment and expand exports. Following the growth of local firms, the guvernment turned to support domestic investments and reduce risks for the firms. In the $1980 \mathrm{~s}$, the government encouraged techmological advances by supporting local firms' $\mathrm{R} \& \mathrm{D}$ investments. Techoological innovation was indeed the most urgent agenda for the state, as well as for local firms, in order to secure Korca's place in the worldwide electronics industry.

The development of the Korean electronics industry sheds light on the role of nationstates and local firms. In this globalized world, it is nut an easy task to conceptualize a model for "national development." The capability of nution-states to manage their conomics has grown weaker, while the international flow of capital, commodity, and labor has increased. But, as we have seen in the case of the Korcan clectronics industry, the greweth of local firms is crucial in promoting technological atvancement and progress into high vilue-added production. The role of the nation-statc can $b x$ an inportant factor in determining a country's developmental path. The nation-state can still inplement measures to cope with external constraints and provicle support for the growth of local firms. (Lew 1987).

\section{REFERENCES}

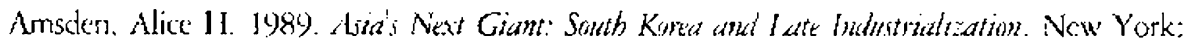
Oxford Iniversity Press.

Chan, Kwok Bun, ed. 2000. Chinese Business Neturrks. Singapore: Prentice Hall.

Chon, Soohyun. 1996. "Development of the Semiconductor Industry in Korea: A Stepping Stone to Join the Ranks of Core Countries?" Competition \& Cbange 1: 259-83.

Cumings, Bruce. 1987. "The Origins and Development of the Northeast Asian Political Country." In the Political Country of the Net Asian Industrialism, ed. Frederic C. Deyo. Ithaca: Cornell Unversicy Press.

Electronic Industries Association of Kurea (EIAK). 19y). Website intornation at litrp:il wrww.ciak org.

Frbel, Folker, Itgen Heninrichs, and Otto Kreye. 1980). The Nete International Dataim of laker. Cambridge: Cambridgc University Press.

Gereffi, Gary. 1992. "New Realities of Industrial Development in East Asia and Latin America: Global, Regional, and Narional Trends." In States and Detelopment in the Lian Paific Rum, eds. Richard P. Appolbaum and Jeffrey Henderson. Newbury Park: Sage.

1994: "Rethinking Development Theory: Jusights from East Asia and Latin America." In Camparative National Dezelopment, eds. A. Douglas Kincaid and Alejandro Portes. Chapel Hill: 'The Liniversity of North Carolinal Press.

1994b. "Capitalism, Development and Global Conmodity Chains". In Capialism and Detelopment, ed. Iestic Sklair. London: Routledge.

149).k. "The Orginization of Buyer-driven Global (emmodity (hains." In Commadit)

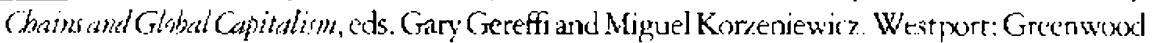
Press.

Crereffi, Gary, Miguel Korzeniewicz, and Kobert P. Korzeniewicz. 1494. "Introduction: Global 
Commodity Chains." In Commodity Chams and Ghobal Cabitalum, eds. Giry Geretti and Miguel Korzenicuicz. Westpurt: Greenwoxd Press.

Gereffi, Gary. and Stephanic Fonda. 1992. "Regional Paths of Develupenent." Ammal Ret iani. of $S_{\text {Kaisos }}$ 18: 419-48.

Hattori, Tamio. and Yukihito Sato, eds. 1996. Kankeke Taitum mo Hatten Mikanizunit [Derelopment Metbanisms in Konea and Taiwan\}. Inssitute of Developing Econonues.

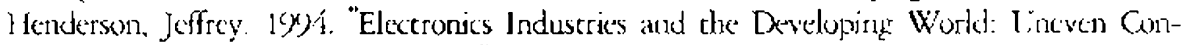
rriburions and Uncerrain Prospects." In Capitalitim and Denxibment, ed. Leslie Sklair. Ionkom: Routicdge.

Hopkins, Terence K., and Immanuel Wallerstein. 1986, "Commodiry Chains in the Worldcconomy Prior to 1800." Review 10: 15\%-/0.

Ichimura, Shinichi. 1998. Politial Eomony of Japanese and Asem Derelopment. Tolyo: Springer. Kim, Eun Mce. 1997. Big Business. Strong State: Collwion and Comflut in South Koredn Lazelopment 1960-1990. Albany: Sate University of Nes' York Press.

Kim, Hyung Kook, and Su-Hoon Lee. 1994. "Commodity Chains and the Korean Autonobile Industry". In Commulity Chains and Glubal Capitalism, eds. Gary Geretfi and Migual Korferniewick Westport: Greenwool Press.

Iatu. Sim-Yer. 1997. "Technology Transter in East Asia and its Implications for Regional Coxperation." Glubal Evmomic Review 26 (4): 65-89.

Lee, Chung H. 1\%)?. "The Government, Finakcial System. and Large Private Enterprises in the Fonomic [Development of Sourh Korea." World Detelemicht 20 (2): 187-97.

lec, Kwang-chul 1995. "A Comparative Analysis of Suth Korea and Japanese Foreign Direct Investments in ASEAN." In ASEAN and Korw: Emerging Issues in Trate and Imestment Rekations, eds. Daljit Singh and Reza Y. Siregar. Inscituce of Southeast Asian Studies.

I.Ew, Scok-Chours. 1987. "Conextual Lffect of Depxondency: A Cross-national Study on Eoo

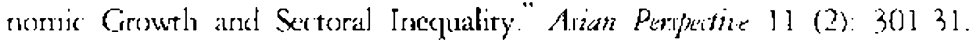

19)6. "Domination Structure and Capieal Accumulation in Contemporary Korea," presented at the annual meering of the American Sociologicial Associatiun, New York.

14)7. "Confucian Capitalism: Possibilities and Limits." Kom Fonct 5 (1): 80-92.

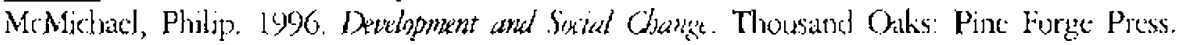

Ornu. Marco. et al. 1997. The Eomomic Oryanization of Fan Asian Capitalism. Thousand Oaks: Sage Publications.

Shin. Roy W. IG)7. "Interactions of Science and Technology Policies in Creating a Competitive Indusery: Korea's Electronics Industry," Global kommi ketiek 26 (4): 3-19.

Sirikrai, Surachai. 199.1. "Japan and Asian NJES' Direct Investnent in ASEAN's Manufacturinge and its Implications." In Exommic Cooperation in the Lika-Paifo Cimmonty, eds. Jaymin Lee and Young Sun Lee. Institute of East and West Studies, Yonsei Liniversity.

Tan, Gerald. 1996. ASEAN Eonomic Dertopment and Co-sthratim. Singapore: Times Academic Press.

Wang, Yen Kyun. 1995. "Orerview of ASEAN-South Kurea Eonomic Relations." In ASEAN and Korea: Enenging Lstes in Trade and Inestment Retatishs, eds. Daljir Singh and Reza $Y$. Siregar. Institute of Southeast Asian Studies.

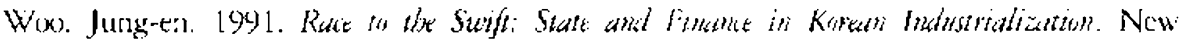
York: Colluntia Inisersity Press.

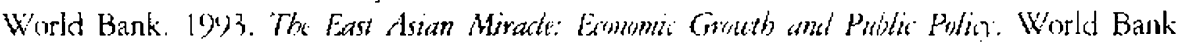
Policy Rescarch Rejores. 